\title{
Ginter Dzierżon, Kinga Szymańska, Wpływ zespołu stresu pourazowego na kanoniczną niezdolność do zawarcia małżeństwa, Wydawnictwo Naukowe UKSW, Warszawa 2020, ss. 208
}

\author{
KS. TOMASZ JAKUBIAK \\ Dr hab., prof. Akademii Katolickiej w Warszawie \\ e-mail: kontakt@jakubiaktomasz.pl, https://orcid.org/0000-0003-4781-686X
}

Wydawnictwo Naukowe UKSW wydało w 2020 r. monografię poświęconą wpływowi zespołu stresu pourazowego na możliwość osób nim dotkniętych do zawarcia małżeństwa, rozpatrywaną z punktu widzenia prawa Kościoła katolickiego. Nie ukrywam, że sięgnąłem do niej z dużą ciekawością, z dwóch powodów.

Po pierwsze, profesor Ginter Dzierżon znany jest mi jako wnikliwy badacz, który w swoich publikacjach nie boi się mierzyć z problematyką wcześniej naukowo nieopracowywaną. Wobec tego teksty jego autorstwa zawsze stanowią znaczący przyczynek do rozwoju kanonistyki polskiej, ale nie będzie przesadą również stwierdzenie, że także światowej. Ksiądz profesor od wielu lat zajmuje się tematyką wad zgody małżeńskiej, a zatem recenzowana publikacja jest oparta na dogłębnej analizie problemu. W tym miejscu warto przywołać chociażby niektóre monografie jego autorstwa lub współautorstwa, związane z przedmiotową problematyką: W. Góralski, G. Dzierżon, Niezdolność konsensualna do zawarcia małżeństwa kanonicznego, Wydawnictwo UKSW, Warszawa 2001, ss. 468; G. Dzierżon, Niezdolność do zawarcia małżeństwa jako kategoria kanoniczna, Wydawnictwo UKSW, Warszawa 2002, ss. 364.

Współautorką monografii jest Kinga Szymańska, osoba nieprzypadkowa. W $2018 \mathrm{r}$. obroniła na Wydziale Prawa Kanonicznego UKSW pracę doktorską pisaną pod kierunkiem G. Dzierżona, zatytułowaną Wplyw zaburzeń odżywiania na niezdolność konsensualna do zawarcia małżeństwa. Anoreksja, bulimia, bigoreksja i inne w naukach medycznych, w wyrokach Roty Rzymskiej, w doktrynie kanonistycznej (wydana w 2019 r. w Krakowie przez Wydawnictwo Homo Dei). Stąd w tekstach jej autorstwa poświęconych wadom zgody małżeńskiej można dostrzec metodologię pracy samego promotora. Również w jej przypadku opracowanie zagadnień wymagających gruntownej znajomości doktryny i dyscypliny Kościoła katolickiego w zakresie uregulowanym w kan. 1095 Kodeksu Prawa Kanonicznego zostało poprzedzone wnikliwym studium. 
Drugim powodem, który skłonił mnie do lektury, jest fakt, że przedmiot badań przeprowadzonych przez autorów na rzecz powstania publikacji nie został dotychczas opracowany ani w polskiej, ani w światowej literaturze. Chociaż w ujęciu medycznym po raz pierwszy objaw zespołu stresu pourazowego (Post-traumatic Stress Disorder - PTSD) określono w 1952 r., to w literaturze kanonistycznej nie sposób znaleźć monografii ani nawet artykułu naukowego bezpośrednio poświęconego problematyce wpływu PTSD na kanoniczną niezdolność do zawarcia małżeństwa.

Recenzowana monografia ma strukturę typową dla książek naukowych. Składa się z trzech rozdziałów poprzedzonych wstępem i spisem treści. Każdy z nich podzielony został na mniejsze jednostki redakcyjne, zawierające osobny wstęp i podsumowanie. Całość opracowania zwieńczona została zakończeniem, wykazem skrótów oraz obszerną bibliografią z licznymi pozycjami obcojęzycznymi. Nie zabrakło również anglojęzycznego podsumowania i spisu treści.

We wstępie przybliżone zostało czytelnikowi pojęcie zespołu stresu pourazowego. Przytoczone zostały również liczne terminy określające jednostkę chorobową, o której mowa w tytule książki. G. Dzierżon wraz z K. Szymańską uzasadnili powody, dla których, analizując przedmiotowe zagadnienie, odwołali się do opracowań psychologicznych i psychiatrycznych na temat PTSD. Ich zdaniem uzasadnienie sformułowanej hipotezy było niemożliwe bez odniesienia do wspomnianych dyscyplin naukowych.

Pierwszy rozdział zatytułowano Historia badań nad zespołem stresu pourazowego, w którym zaznaczono, że kamieniem milowym w rozwoju badań naukowych nad stresem pourazowym były doświadczenia żołnierzy amerykańskich w czasie wojny w Wietnamie. Niezwykle ciekawy jest podrozdział przybliżający czytelnikowi pierwsze opisy PTSD w literaturze. Ukazano w nim najstarsze wzmianki o symptomach tego zaburzenia, pochodzące sprzed pięciu tysięcy lat. Niejaki Ben-Ezra opisał zaburzenia snu i wszechogarniający niepokój jako następstwo śmierci króla UR-Nammu (2111-2094 r. p.n.e.) oraz zniszczenia miasta Ur (2026-2003 r. p.n.e.). Chociaż literatura od tego momentu zawierała opisy traumy psychologicznej, to jednak badania medyczne nad nią rozpoczęły się dopiero w XVIII w.

Początkowo traumę wiązano z działaniami wojennymi. Rozwój przemysłu w XIX w. oraz liczne wypadki za jego sprawą, do których dochodziło wśród ludności, uświadomiły badaczom, że zaburzenia stresu pourazowego nie są domeną wyłącznie wojskowych, ale występują również u cywilów w okresie tzw. pokoju. Tragedie II wojny światowej, w tym holokaust ludności żydowskiej, również stały się przyczynkiem do dalszych badań nad tym syndromem.

Już na początku drugiego rozdziału pt. Zespół stresu pourazowego w naukach medycznych można odnaleźć informację, że dotknięta nim może być znaczna część 
populacji. Naomi Breslau i Ronald C. Kassler dowiedli, że 90\% badanych osób doświadczyło przynajmniej jednego traumatycznego wydarzenia w życiu. Częstszymi katalizatorami omawianego w książce zaburzenia są traumy wywołane przez ludzi, jak wojna lub terroryzm, niż zdarzenia powstałe losowo lub katastrofy naturalne. PTSD powodować mogą zarówno wydarzenia cykliczne, jak i jednorazowe, obejmujące jednocześnie grupy albo tylko jednostki.

Przedmiotem badań przedstawionych w drugim rozdziale stały się objawy, kryteria diagnostyczne oraz etiopatogeneza. Wśród symptomów choroby można wyróżnić cztery główne kryteria: nawracające wspomnienia doświadczanej niegdyś traumy, unikanie bodźców związanych ze stresem, nadmierne pobudzenie organizmu oraz negatywne zmiany poznawcze i nastroju. Symptomy PTSD są przewlekłymi zaburzeniami poznawczymi, emocjonalnymi, behawioralnymi, somatycznymi. Zatem nie ma się co dziwić, że mogą one mieć wpływ na zdolność konsensualną osób nią dotkniętych.

G. Dzierżon i K. Szymańska szczegółowo opisali przebieg zespołu u: dzieci dotkniętych traumą, żołnierzy, osób przebywających w obozach koncentracyjnych i więzieniach, a także osób zawodowo zajmujących się udzielaniem pomocy. Niestety, tylko w przypadku dzieci oraz żołnierzy autorzy wskazali bezpośredni wpływ traumy doświadczonej przez te grupy badanych na ich funkcjonowanie w małżeństwie. Dzisiaj, w dobie zmagań z pandemią koronawirusa Covid-19, warto byłoby, by autorzy w kolejnym opracowaniu rozważyli uzupełnienie podrozdziału poświęconego symptomom stresu pourazowego u osób zawodowo zajmujących się niesieniem pomocy o analizę wpływu tego zaburzenia na życie małżeńskie. Co rusz w mediach pojawiają się informacje o traumie, jakiej obecnie doświadczają medycy ze względu na liczbę umierających pacjentów, którym nie są w stanie udzielić wystarczającej pomocy. Z pewnością doświadczenia te będą miały wpływ na życie małżeńskie osób wykonujących zawody medyczne.

Jeśli chodzi o kryteria diagnostyczne PTSD, należy zauważyć, że są one zróżnicowane w zależności od tego, czy system je określający opracowany został przez WHO (International Classification of Diseases, Injuries and Causes of Death - ICD) czy też przez Amerykańskie Towarzystwo Psychiatryczne (Diagnostic and Statistical Manual of Mental Disorders - DSM). Różnice pomiędzy kryteriami występujące w DSM i ICD generują problemy diagnostyczne, co zostało trafnie ukazane przez autorów.

Ostatni podrozdział drugiej części książki poświęcony został etiopatogenezie PTSD. Generalnie obejmuje ona - oprócz samego zdarzenia traumatycznego - predykatory psychologiczne, środowiskowe i genetyczne. Na uwagę zasługuje fakt, że istnieje naukowo potwierdzone wyższe ryzyko wystąpienia zespołu u osób 
z osobowością: borderline, lękliwą, anankastyczną, schizoidalną, ludzi cierpiących na aleksystemię. Jeśli chodzi o czynniki rodzinne, część naukowców prezentuje opinię, że środowisko rodzinne jest pierwszym czynnikiem generującym wystąpienie PTSD. G. Dzierżon i K. Szymańska cytują Katarzynę Litwińską-Rączkę, która jako źródło traumy wymieniała następujące zagrożenia ze strony rodziców bądź opiekunów dziecka: sytuacje przemocowe, wykorzystanie seksualne, zaniedbanie podstawowych potrzeb fizycznych, emocjonalnych i rozwojowych. Rachel Yehuda w 2015 r. potwierdziła natomiast, że zmiany epigenetyczne w DNA dzieci są wyraźnie związane z urazem psychicznym rodziców bądź przeżytą przez nich traumą.

Ostatni rozdział, jak sam jego tytuł precyzuje (Wpływ zespołu stresu pourazowego na niezdolność do zawarcia małżeństwa w orzecznictwie Roty Rzymskiej), poświęcony został analizie wyroków trybunału Stolicy Apostolskiej, w których wzmiankuje się o PTSD występującym u stron procesowych. Do dnia wydania monografii spośród zaprezentowanych w niej wyroków i dekretów opublikowane zostały jedynie cztery. Wartością dodaną tego opracowania stało się zatem wykorzystanie na rzecz jej powstania wyroków nieopublikowanych. Było to możliwe dzięki uprzejmości Prodziekana Roty Rzymskiej Maurice’a Moniera.

Odnotować należy, że dotychczas Rota nie prowadziła spraw, których przedmiot wprost stanowiłoby oddziaływanie zespołu stresu pourazowego na niezdolność konsensualną. Tę kwestię rozpatrywała jedynie pobocznie. Wątek PTSD częściej pojawiał się w uzasadnieniach faktycznych wyroków w postępowaniach prowadzonych z tytułów określonych w kan. 1095 n. 2-3 KPK niż w uzasadnieniach prawnych.

Analiza wyroków i dekretów wydanych przez trybunał Stolicy Apostolskiej pozwala dostrzec nieco inną praktykę sądów kościelnych polskich w stosunku do sądu rzymskiego. Podczas gdy trybunał biskupa rzymskiego często rozpatrywał ważność małżeństwa osób dotkniętych PTSD jednocześnie z kan. 1095 n. 2 i 1095 n. 3 KPK, uzasadnienia faktyczne wyroku pozwalają z dużym prawdopodobieństwem przypuszczać, że w sądach polskich sprawy te byłyby badane pod kątem tytułu z kan. 1095 n. 3 KPK. Sędziowie sądów polskich przy rozpatrywaniu nieważności małżeństwa z powodu wady zgody małżeńskiej chętniej sięgają do tytułu zapisanego właśnie w numerze trzecim przywołanego kanonu.

Nie ukrywam, że podczas lektury ostatniego rozdziału moją uwagę przykuły dwa opisane w nim wyroki. Pierwszy z dnia 27 kwietnia 2010 r. (Sent. 64/2010, Mediolanen., Dec. c. Alwan z 27.04.2010). W jego uzasadnieniu prawnym ponens zauważyl, że czas ustania zaburzenia może być różny, gdyż proces ten jest uzależniony od czynników subiektywnych. Zwrócił także uwagę, iż z badań klinicznych wynika, że mimo przezwyciężenia zaburzenia stan psychiczny osoby, po której stronie zachodziła niezdolność, nie pozostaje bez wpływu na jej proces dojrzewania, 
w sposób szczególny na funkcjonowanie władz afektywnych. Stwierdził także, że wspomnienia traumatycznych, nierozwiązanych w świadomości wydarzeń mogą destrukcyjnie oddziaływać na mechanizmy obronne nupturienta. Drugi wyrok, który przykuł moją uwagę, to 258/2013, Paupolitana et Minneapolitana., Dec. c. McKay z 26.07.2013 (nieopublikowany). Biegli wykazali w nim, że choć były żołnierz w przeszłości był dotknięty PTSD, to jednak w chwili zawierania związku nie wykazywał symptomów charakterystycznych dla zespołu. Wobec tego turnus rotalny zawyrokował w nim pro validitatae matrimonii.

Na marginesie warto zauważyć, że wcześniej w wyroku c Huber z dnia 22 czerwca 2005 r. (75/2006, Bostonien., Dec. c. Huber z 22.06.2005) ponens, odnosząc się do kwestii wpływu motywów podświadomych na świadomość osoby, stwierdził, że z niezdolnością mamy do czynienia wtedy, gdy nupturient nie potrafi sobie poradzić z motywami podświadomymi. W przywołanej sprawie było inaczej. Zatem sędziowie orzekli ważność małżeństwa. Jak wynika z lektury przytoczonych wyroków, wykazanie w procesie zaistnienia PTSD u nupturienta nie musi być tożsame $\mathrm{z}$ udowodnieniem jego niezdatności do zawarcia małżeństwa $\mathrm{z}$ tytułów opisanych w kan. 1095 n. 2-3 KPK.

W zakończeniu ostatniego rozdziału autorzy zauważyli, że choć ekspertyzy biegłych w sprawach rozpatrywanych z przyczyny niezdolności osoby do zawarcia małżeństwa spowodowanej PTSD są istotnym dowodem, to jednak nie jedynym. $\mathrm{W}$ badanych wyrokach fakty przytaczane przez strony przeważnie potwierdzone były w zeznaniach świadków.

Kończąc recenzję, chciałbym zauważyć, że i tym razem nie zawiodłem się na autorach. Lektura monografii spełniła moje oczekiwania. G. Dzierżon wraz K. Szymańską wydali kolejną książkę, która niewątpliwie wnosi duży przyczynek do rozwoju kanonistyki. Zasygnalizowane we wstępie cele badawcze zostały zrealizowane w stu procentach.

Metodologia badań została odpowiednio dobrana. Była ona zróżnicowana ze względu na cele, jakie przyświecały powstaniu każdego z rozdziałów. Stąd w pierwszym rozdziale posłużono się metodą historyczną. W drugim dominowała metoda syntetyczna. W trzecim natomiast skorzystano z metody krytycznej źródeł.

Ze względu na przedmiot badań publikacja ma charakter interdyscyplinarny. Wiele w niej odniesień do wyników badań nauk medycznych, choć nie brakuje nawiązania do literaturoznawstwa. Nie przyczyniło się to jednak w najmniejszym stopniu do zubożenia wartości monografii jako publikacji kanonistycznej.

Czy poleciłbym książkę? Z pewnością tak. Szczególnie powinny zapoznać się z nią osoby na co dzień zaangażowane w prace trybunałów kościelnych zajmujących się badaniem ważności małżeństw. Pomocna będzie przy procesach toczących 
się z tytułu nie tylko niezdolności osoby do zawarcia małżeństwa z powodu występowania zespołu stresu pourazowego u nupturientów, ale z wszystkich przyczyn powodujących niemożność, o której mowa w kan. 1095 n. 2-3 KPK. Doskonale ukazuje bowiem metodykę przeprowadzenia dowodów w tego typu sprawach, jak również interpretację przywołanych norm prawnych. 